\author{
dr hab. Beata BIESZK-STOLORZ \\ Wydział Nauk Ekonomicznych i Zarządzania, Uniwersytet Szczeciński \\ e-mail: beatus@wneiz.pl \\ dr hab. Iwona MARKOWICZ, prof. US \\ Wydział Nauk Ekonomicznych i Zarządzania, Uniwersytet Szczeciński \\ e-mail: iwona.markowicz@wneiz.pl
}

DOI: $10.15290 /$ oes.2018.01.91.01

\title{
APPLICATION OF MODELS OF SURVIVAL ANALYSIS IN THE ASSESSMENT OF THE SITUATION OF MACROSECTORS OF LISTED COMPANIES
}

\begin{abstract}
Summary
Goal - The goal of the article is the assessment of the possibilities of recovery after decrease of prices of shares of companies listed on the Warsaw Stock Exchange in the years 2008-2009 and 20112013 in particular macrosectors: industrials, financials and services. The probability and intensity of increase and decrease of prices were analysed.

Research methodology - Selected methods of survival analysis were applied. The Kaplan-Meier estimator was used in the analysis of the probability of increase and decrease of prices of shares in the macrosectors. The intensity of decrease and increase of prices was assessed by means of the empirical hazard model and the proportional Cox model. Threshold values of the increase and decrease of prices were calculated on the basis of changes of the WIG index in analysed periods. Comparative analysis of these two periods was also conducted.

Score - The hypothesis about a similar situation of macrosectors during the financial crisis and in the bear market was confirmed. In case of the financials macrosector, its reaction to the market situation was the strongest in both the decrease and increase of share prices. The companies of the industrials macrosector were in better situation than the financial companies. The service companies reacted weakly on the market changes.

Originality /value - The application of the survival analysis methods in the study of the capital market.
\end{abstract}

Key words: survival analysis, listed companies, bear market, macrosectors

JEL classification: C10, C14, C41, G01

\section{Introduction}

The maximum drop of the WIG values, comprising the companies listed on the Warsaw Stock Exchange (WSE) main market, was in 2008. The slump period was a result of the world crisis of 2008/2009. The next year with negative rates of return on the WIG was 2011. The analysts point out that it was the year when the over 
a decade-long regularity that the indexes grow along with increasing turnover abruptly came to an end [Rocznik Giełdony 2012, pp. 23-24]. That was a year of heightened investor activity, the effect of which was the record turnover of shares and derivatives. Unfortunately, the drop in company values in the second half of 2011 resulted in the fall of the WIG value by $20.8 \%$ (Fig. 1). Olbryś and Majewska (2015) presented an interesting method for identification of a crisis. They used the Pagan-Sossounov framework for analysing bear and bull markets to determine the crisis stages based on the analysis of monthly logarithmic rates of return on the main indexes of the Warsaw Stock Exchange, i.e. WIG and of the New York Stock Exchange, i.e. S\&P 500 US. From the definition of boom/slump it results that there must be at least $20 \%$ of increase/decrease of prices in the quotations. The period of the 2011 bear market was not as spectacular as the 2007-2009 one, yet WIG dropped by at least 20\% (27\% from April 7 to September 23, 2011), S\&P 500 US dropped by at least $20 \%$ too (20\% from April to October 2011) [http://biznes.pl/ gielda.....

FIGURE 1.

Rates of return on the WIG in 2005-2015 (\%)

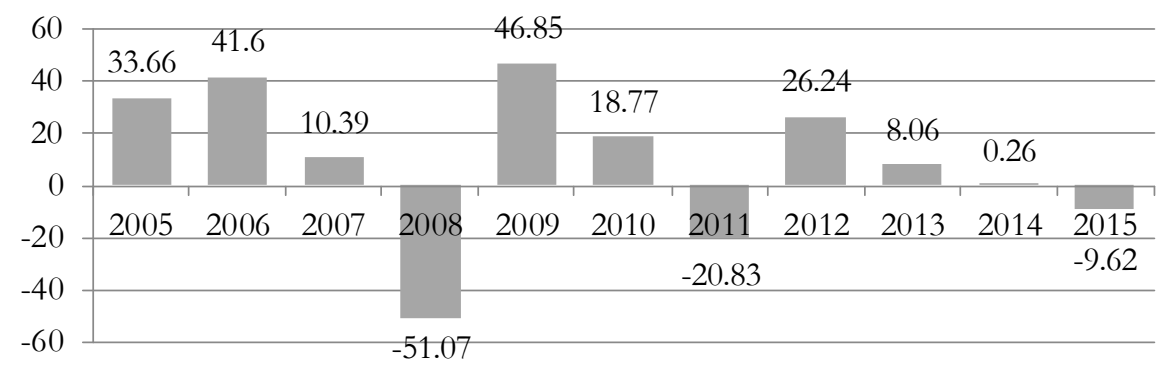

Source: GPW database.

The goal of the article is the assessment of the possibilities of recovery after decrease of prices of shares of companies listed on the Warsaw Stock Exchange in the years 2008-2009 (period I - crisis) and 2011-2013 (period II - bear market) in particular macrosectors. The specific objectives of this study are as follows:

- The assessment of the probability and intensity of decrease and increase of prices of shares in particular macrosectors during the crisis (2008-2009) (objective 1).

- The assessment of the probability and intensity of decrease and increase of prices of shares in particular macrosectors in the bear market (2011-2013) (objective 2).

- Comparison of the situation in the stock market macrosectors in the observed period of the bear market (2011-2013) and during the financial crisis (2008-2009) (objective 3).

The hypotheses have been set that the situations of macrosectors of listed companies in the analysed bear market and during the crisis were similar. 
Performed analysis is the extension of earlier research referring the increase and decrease of prices in the bear market (2011) on the WSE [Bieszk-Stolorz, Markowicz, 2011; Bieszk-Stolorz, Markowicz, 2017]. It was supplemented with the conclusions resulting from the Kaplan-Meier estimator and the empirical hazard model for the periods 2008-2009 and 2011-2013.

\section{Data used in the research}

The study is based on the data of 328 (period I - 2008-2009) and 378 companies (period II - 2011-2013). These were the companies listed in whole analysed periods. They were grouped in 3 macrosectors (Table 1). Their closing prices were taken into account.

TABLE 1.

\section{Sectors included in the macrosectors}

\begin{tabular}{|l|l|}
\hline Macrosectors & \multicolumn{1}{|c|}{ Sectors } \\
\hline Industrials & $\begin{array}{l}\text { construction, chemicals, wood \& paper, electro engineering, pharmaceuti- } \\
\text { cal, building materials, light, metals, automobiles, oil \& gas, other indust- } \\
\text { ries, food, basic materials, plastics materials }\end{array}$ \\
\hline Financials & banking, developers, finance other, capital market \\
\hline Services & $\begin{array}{l}\text { energetics, retail trade, wholesale trade, hotels \& restaurants, IT, media, } \\
\text { telecom, other services }\end{array}$ \\
\hline
\end{tabular}

Source: GPW database.

In the years 2008-2009 the authors considered a $60 \%$ decrease of prices from the maximum value and an $80 \%$ increase of prices from the minimum value for each company. However, in the second period (2011-2013) a 30\% decrease and $40 \%$ increase were considered. Assessment of the threshold values of $60 \% / 80 \%$ and $30 \% / 40 \%$ resulted from the observations of the WIG index in the analysed periods. In 2008 the maximum WIG value was 55,702.46 (January $2^{\text {nd }} 2008$ ) and the minimum $-21,320.83$ (February $17^{\text {th }} 2009$ ). It was about a $60 \%$ decrease. The $80 \%$ increase from the minimum value was on August 24th 2009 (38,232.13). On the other hand, in 2011 the maximum WIG value was 50,501.79 (April 11th 2011) and the minimum - 35,348.98 (September 11th 2011). It was a 30\% decrease. The return to the maximum value forced the increase of the WIG index by about $40 \%$. That was in the year 2013. The duration to achieve set thresholds for each company was observed. Not all companies achieved the required threshold values. In such cases, these observations were considered as censored. Table 2 presents the number of companies in analysed macrosectors with the consideration of uncensored and censored observations. 
TABLE 2.

Number of companies in macrosectors

\begin{tabular}{|l|c|c|c|c|c|}
\hline \multirow{2}{*}{ Macrosectors } & \multicolumn{2}{|c|}{ Decrease } & \multicolumn{2}{c|}{ Increase } & \multirow{2}{*}{ Total } \\
\cline { 2 - 6 } & $\begin{array}{c}\text { Uncensored } \\
\text { observations }\end{array}$ & $\begin{array}{c}\text { Censored } \\
\text { observations }\end{array}$ & $\begin{array}{c}\text { Uncensored } \\
\text { observations }\end{array}$ & $\begin{array}{c}\text { Censored } \\
\text { observations }\end{array}$ & \\
\hline \multicolumn{7}{|c|}{ Period I (2008-2009) } \\
\hline Industrials & 119 & 29 & 117 & 31 & 148 \\
\hline Financials & 47 & 5 & 41 & 41 & 128 \\
\hline Services & 97 & 31 & 87 & 83 & 328 \\
\hline Total & 263 & 65 & 245 & 24 & 160 \\
\hline \multicolumn{7}{|c|}{ Period II (2011-2013) } & 136 & 9 & 78 \\
\hline Industrials & 141 & 19 & 69 & 26 & 140 \\
\hline Financials & 72 & 6 & 114 & 59 & 378 \\
\hline Services & 117 & 23 & 319 & & \\
\hline Total & 330 & 48 & \multicolumn{2}{|c|}{} \\
\hline
\end{tabular}

Source: own study based on the GPW database.

\section{Methodology of the research}

Models used in the article belong to the family of survival analysis methods. These methods are commonly used in demography and medicine for analysis of the duration of human life. The duration is in this case considered as the random variable $T$. The basis of all considerations is the survival function $S(t)=P(T>t)$. It defines the probability of the survival of a human until the time $t$. The survival analysis methods can also be used for the duration analysis of any social-andeconomic phenomenon (for example the time of the decrease and increase of shares prices). The advantage of these methods over other ones is the possibility to consider the right-censored observations (not the occurrence of events before the end of the observation period). Survival analysis methods are rarely used in capital market analysis. However, in foreign literature there have been attempts to use them in this area [Lunde, Timmermann, 2004; Deville, Riva, 2007; Markovitch, Golder, 2008].

The probability of survival was assessed by means of the Kaplan-Meier estimator [Kaplan, Meier, 1958]:

$$
\hat{S}\left(t_{i}\right)=\prod_{j=1}^{i}\left(1-\frac{d_{j}}{n_{j}}\right) \text { for } i=1, \ldots, k
$$

where:

$t_{i}-$ the point in time when at least one event occurred, $t_{1}<t_{2}<\ldots<t_{k}, t_{0}=0$;

$d_{i}$ - the number of events in the time $t_{i}$;

$n_{i}$ - number of units under observation in the time $t_{i}, n_{i}=n_{i-1}-d_{i-1}-z_{i-1}$,

$z_{i}$ - number of observations censored in the time $t_{i}$. 
On the basis of the survival function, the quartiles of the duration can be estimated. It is the survival time at which the survival function is equal to $0.75,0.5$, 0.25 , respectively. Survival functions for two groups can be compared. Usually, distributions of the duration are unknown. In such cases, non-parametric, based on the rank order of the duration, tests are used. There are no commonly accepted methods of selection of a test in a given situation. Most of them yield reliable results only for large samples, while the effectiveness of these tests for small samples is less recognised. For comparison of two survival curves, the log-rank test is commonly used [Kleinbaum, Klein, 2005]. It is used for verification of hypothesis $H_{0}: S_{1}(t)=$ $S_{2}(t)$ stating that the survival curves for both groups are the same. Assuming that the null hypothesis is true, the test statistics is chi-square distributed with one degree of freedom.

The estimator of the hazard function (empirical hazard) was used for the analysis of intensity (hazard) of decrease and increase of share prices. It is calculated by means of the following formula [Balicki, 2006, p. 85]:

$$
\hat{h}_{i}=\frac{d_{i}}{c_{i} n_{i}} \text { for } i=1, \ldots, k
$$

where:

$d_{i}$ - the number of events in the time $t_{i}$;

$n_{i}$ - number of units under observation in the time $t_{i}$,

$c_{i}$ - length of time interval from $t_{i}$ until $t_{i+1}$.

The analysis of the relative intensity of the price decrease and recovery is conducted by means of the Cox model regression [Cox, Oakes, 1984], which is also called the model of proportional hazards [Bieszk-Stolorz, Markowicz, 2012; Landmesser, 2013]. The model can be written:

$$
h\left(t: x_{1}, x_{2}, \ldots, x_{n}\right)=h_{0}(t) \exp \left(\beta_{1} x_{1}+\beta_{2} x_{2}+\ldots+\beta_{n} x_{n}\right)
$$

where:

$d_{i}$ - the number of events in the time $t_{i}$,

$n_{i}-$ number of units under observation in the time $t_{i}, n_{i}=n_{i-1}-d_{i-1}-z_{i-1}$,

$h\left(t: x_{1}, x_{2}, \ldots, x_{n}\right)$ - hazard with the data of $n$ independent variables $x_{1}, x_{2}, \ldots, x_{n}$ and the adequate survival time $t$,

$h_{0}(t)$ - reference hazard or baseline hazard;

$\beta_{1}, \beta_{2}, \ldots, \beta_{n}$ - model coefficients;

$t$ - the time of observation.

In order to interpret the relative intensity of the decrease/recovery of the company share prices, the hazard ratios $\left(\mathrm{HR}=\exp \left(\beta_{i}\right)\right)$ for 3 macrosectors $\left(x_{i}-\right.$ dummy variables describing macrosectors) were determined.

In the study the $-1 ; 0 ; 1$ coding of the explanatory variables (macrosectors) was used. It enabled the comparison of intensity of decrease and increase of share prices in the macrosectors with the mean intensity of analysed subgroups [Hosmer, Lemeshow, 2000; Markowicz, Stolorz, 2009]. 


\section{Research results}

In the first stage of the analysis the Kaplan-Meier estimators were calculated (Figures 2-3). The probability of not achieving the threshold decrease and increase of share prices of analysed macrosectors was analysed. The hypothesis of the similarity of the duration functions for the pairs of macrosectors was verified by means of the log-rank test (Table 3).

FIGURE 2.

Kaplan-Meier estimator for macrosectors during the decrease and increase in shares prices of companies in 2008-2009

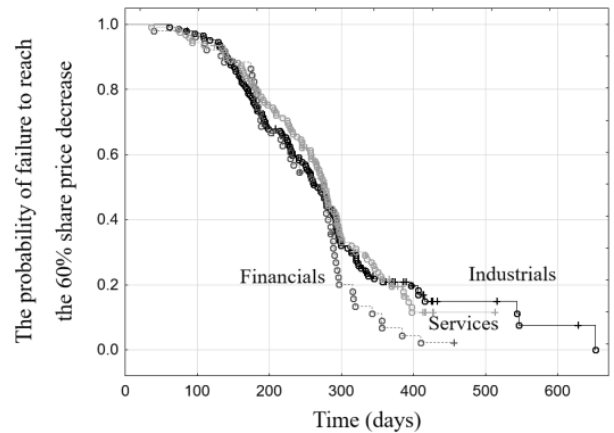

decrease

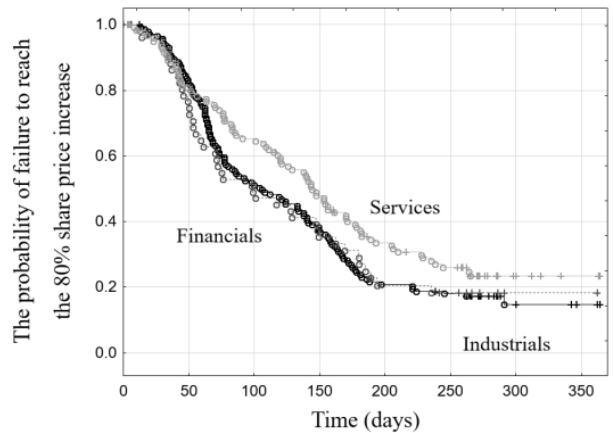

increase

Source: own study.

FIGURE 3.

Kaplan-Meier estimator for macrosectors during the decrease and increase in shares prices of companies in 2011-2013

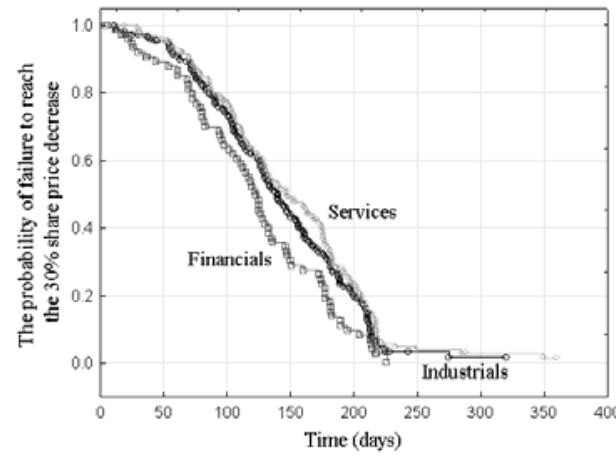

decrease

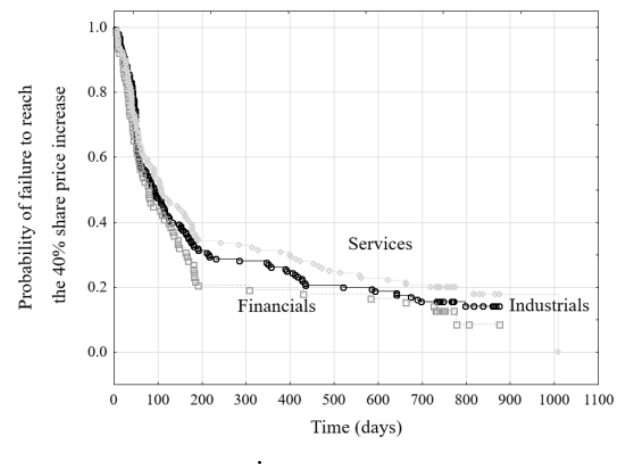

increase

Source: own study. 
TABLE 3.

The results of log-rank test for paired macrosectors during the decrease and increase in shares prices

\begin{tabular}{|l|c|c|}
\hline \multirow{2}{*}{ Macrosectors pairs } & \multicolumn{2}{c|}{ Test $(p$-value $)$} \\
\cline { 2 - 3 } & \multicolumn{3}{c|}{ Decriod I $(2008-2009)$} \\
\hline Industrials-Financials & $1.7136(p=0.0866)$ & $0.0708(p=0.9436)$ \\
\hline Industrials-Services & $-0.2113(p=0.8326)$ & $-1.9403(p=0.0524)$ \\
\hline Financials-Services & $-1.9562(p=0.0504)$ & $-1.4240(p=0.1545)$ \\
\hline & Period II $(2011-2013)$ & $-1.0670(p=0.2846)$ \\
\hline Industrials-Financials & $-2.0501(p=\mathbf{0 . 0 4 0 4})$ & $0.9677(p=0.3332)$ \\
\hline Industrials-Services & $1.0200(p=0.3077)$ & $1.7901(p=0.0734)$ \\
\hline Financials-Services & $2.8340(p=\mathbf{0 . 0 0 4 6})$ & \\
\hline
\end{tabular}

Source: own study of Bieszk-Stolorz, Markowicz [2017].

The test did not confirm the differences in the progression of survival curves in the years 2008-2009. However, in the period 2011-2013 the results imply that during the price decrease the progression of the survival function for the financials macrosector differed from the other macrosectors. The companies in the financials macrosector noted a decrease of share prices quicker than other companies. At the time of price recovery, however, the progression of the survival functions were similar in all the macrosectors. In order to compare the probability of price decrease and increase until the time $t$, quartiles of duration were estimated (Table 4).

Quartiles of duration (months)

TABLE 4.

\begin{tabular}{|l|c|c|c|c|c|c|}
\hline \multirow{2}{*}{ Macrosectors } & \multicolumn{3}{|c|}{ Decrease } & \multicolumn{3}{c|}{ Increase } \\
\cline { 2 - 7 } & Lower quartile & Median & Upper quartile & $\begin{array}{c}\text { Lower } \\
\text { quartile }\end{array}$ & Median & $\begin{array}{c}\text { Upper } \\
\text { quartile }\end{array}$ \\
\hline \multicolumn{7}{|c|}{ Period I (2008-2009) } \\
\hline Industrials & 5.94 & 8.79 & 10.80 & 2.00 & 3.45 & 5.83 \\
\hline Financials & 6.04 & 9.01 & 9.65 & 1.64 & 3.24 & 6.08 \\
\hline Services & 6.59 & 9.07 & 11.37 & 2.29 & 4.72 & 8.52 \\
\hline \multicolumn{7}{|c|}{ Period II $(2011-2013)$} \\
\hline Industrials & 3.21 & 4.60 & 6.20 & 1.51 & 2.99 & 12.89 \\
\hline Financials & 2.62 & 4.03 & 5.71 & 1.12 & 2.56 & 5.93 \\
\hline Services & 3.39 & 4.83 & 6.46 & 1.41 & 3.52 & 16.08 \\
\hline
\end{tabular}

Source: own study. 
In period I the price decrease was the fastest for the industrials macrosector, while in period II - for the financials macrosector. The fastest increases for both periods I and II were observed for the financials macrosector. In both analysed periods the slowest decrease and next increase of share prices was observed for the services macrosector. For example, the highest value in table 4 informs us that $75 \%$ of the service companies noted a $40 \%$ increase of prices after 16 months.

Further part of the analysis consisted of the assessment of intensity (hazard) of decrease and increase of prices with the use of the empirical hazard model (Figures 4-7).

Intensity of price decrease in the years 2008-2009

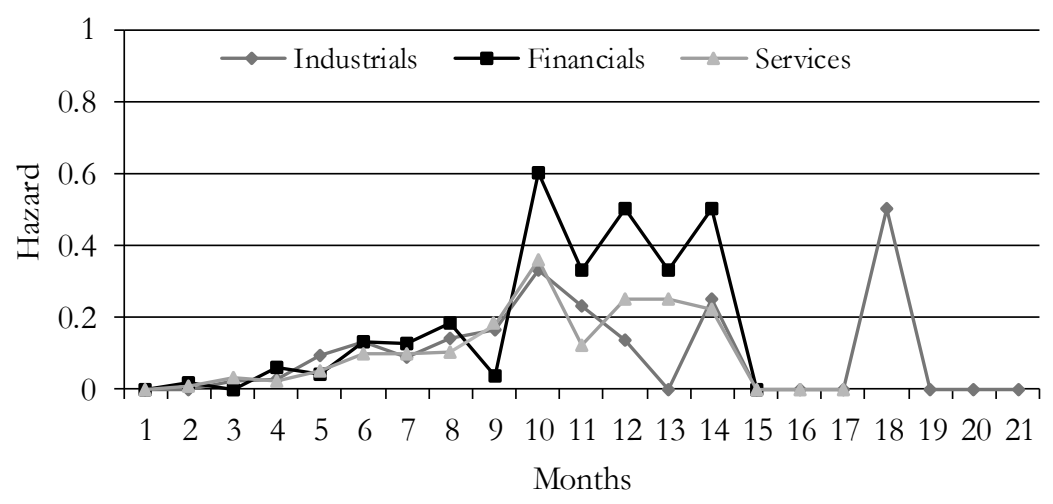

Source: own study.

Intensity of price increase in the years 2008-2009

FIGURE 5.

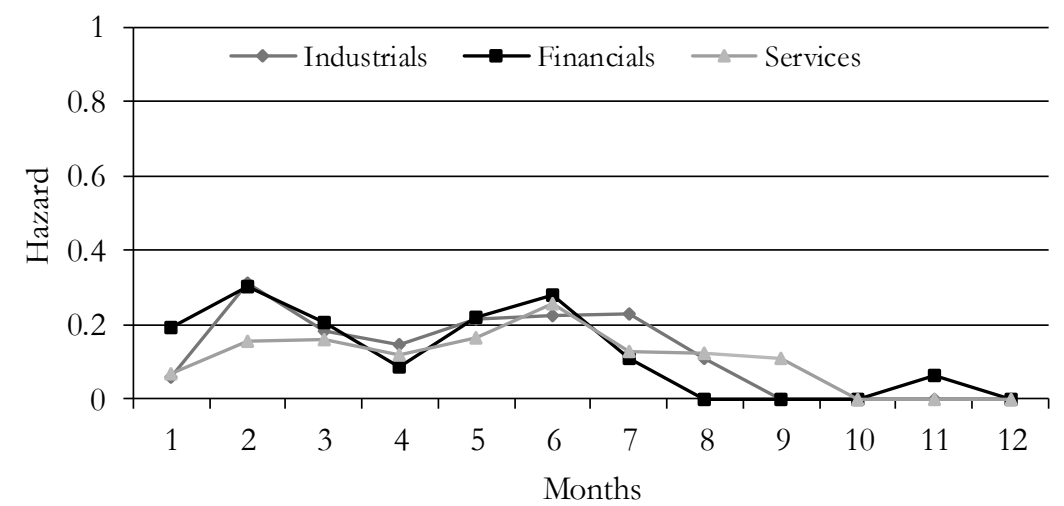

Source: own study. 
FIGURE 6.

Intensity of price decrease in the years 2011-2013

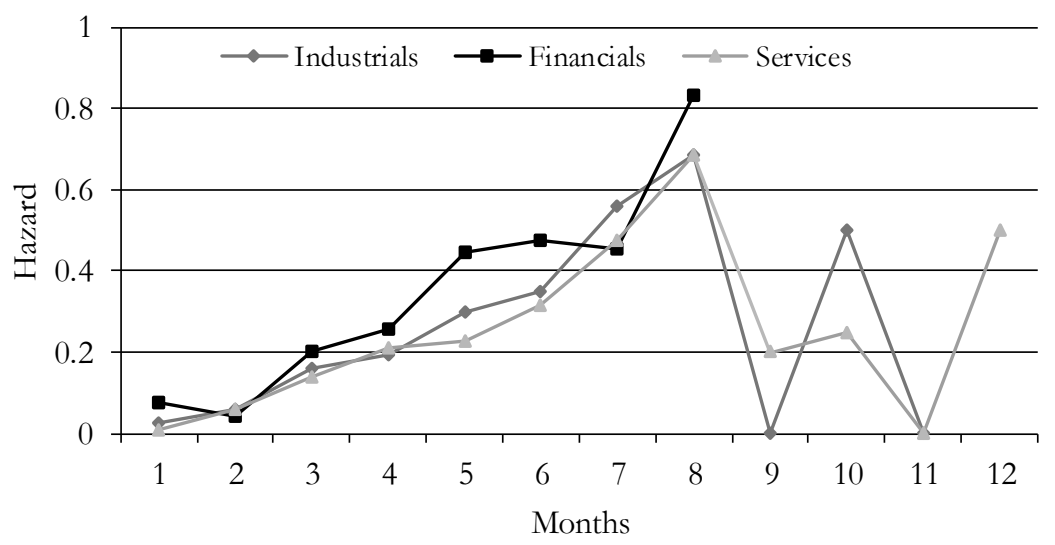

Source: own study.

In this case the intensity expresses the frequency of occurrence of the event in the time unit (month). In both periods the intensity of the price decrease is lower in the first months. What is characteristic is the fact that this intensity reaches its maximum for companies of all sectors in the same months: in the $10^{\text {th }}$ month in the years 2008-2009 and in the $8^{\text {th }}$ month in the years 2011-2013. On the other hand, in the case of recovery, higher intensity takes place in the first months and gets weaker afterwards.

FIGURE 7.

Intensity of price increase in the years 2011-2013

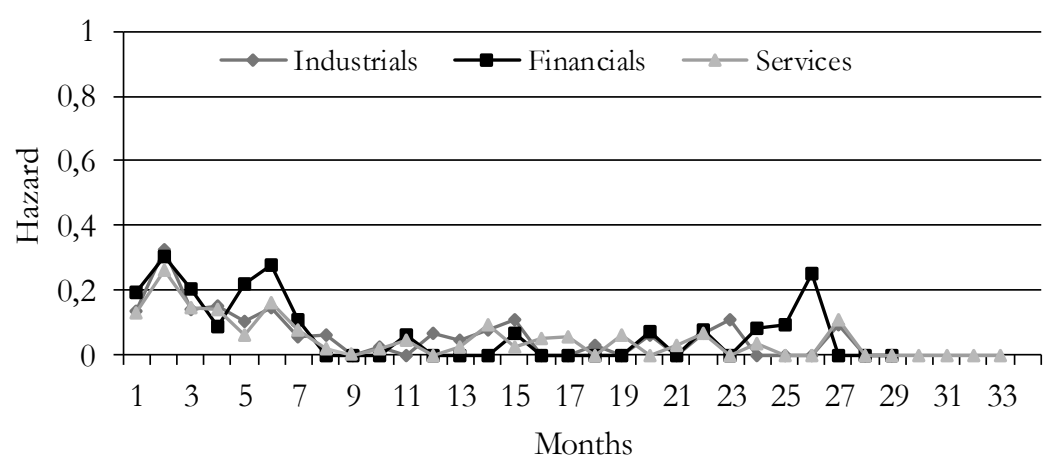

Source: own study.

The parameters of the Cox regression model help to assess the relative intensity of the price decrease and recovery in the macrosectors. For this purpose, the hazard ratios were estimated. The relative intensity is a comparison of a given group's 
intensity with the one determined for the reference group (in this study, with mean intensity). The relative intensity bigger than 1 shows that the intensity of a price decrease and recovery in a given macrosector is higher than the average. Companies in the financials macrosector reacted the most strongly to the declining situation and then recovered quickly (the highest values of the hazard ratios, table 5). The smallest relative intensity of decrease and increase of share prices in both periods were typical for the companies in the services macrosector. Comparing the data from tables 5 and 2 it can be stated that the companies in this macrosector reacted least to the crisis situations. This macrosector had the largest share of companies that did not reach the decrease threshold.

TABLE 5.

The relative intensity of decrease and increase of share prices in macrosectors in the years 2008-2009 and 2011-2013

\begin{tabular}{|l|c|c|}
\hline \multirow{2}{*}{ Macrosectors pairs } & \multicolumn{2}{|c|}{ Relative intensity (HR) } \\
\cline { 2 - 3 } & Decrease & Increase \\
\hline \multicolumn{3}{|c|}{ Period I (2008-2009) } \\
\hline Industrials & 0.9075 & 1.0895 \\
\hline Financials & 1.2466 & 1.1031 \\
\hline Services & 0.8840 & 0.8321 \\
\hline \multicolumn{3}{|c|}{ Period II (2011-2013) } \\
\hline Industrials & 0.9395 & 0.9870 \\
\hline Financials & 1.2901 & 1.1590 \\
\hline Services & 0.8250 & 0.8742 \\
\hline
\end{tabular}

Source: own study of Bieszk-Stolorz, Markowicz [2017].

\section{The situation of macrosectors during the financial crisis and in the bear market}

The next stage of the analysis was the comparison of the situation in the stock market macrosectors in the observed period of the financial crisis (2008-2009) and in the bear market (2011-2013). Demonstration of the values of stock price decrease intensity and stock price recovery intensity in the form of a diagram helps to identify the areas that are characteristic of the macrosectors situation in the period of price decrease and increase. When the intersection of the axes is set at 1 for both the price decrease risk and the price recovery odds we can distinguish four areas (Figure 8):

1. "low - low"; low intensity of price decrease and recovery.

2. "high - high"; high intensity of price decrease and recovery.

3. "low - high"; low intensity of price decrease followed by high intensity of price recovery.

4. "high - low"; high intensity of price decrease followed by low intensity of price recovery. 


\section{Relative intensities of decrease and increase of share prices by macrosectors}

FIGURE 8.

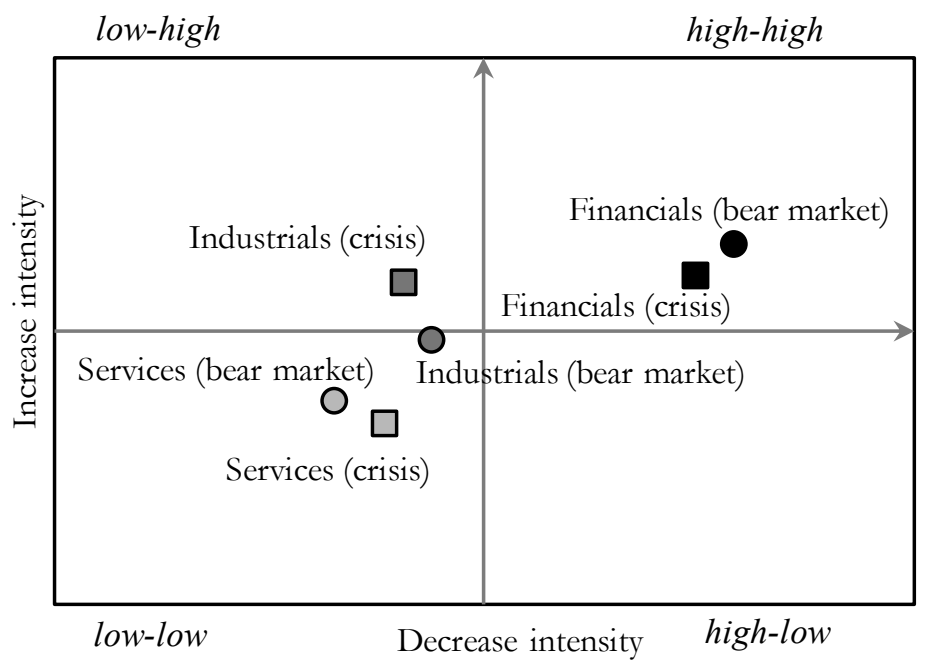

Source: own study.

The first area indicates the weak response to the downturn (low intensities of decrease and increase). The third area is also characterised with low intensity of the price decline but the price recovery intensity ratio is higher than the average. These two areas show that there is no necessity to recover from high losses. The second field signals a strong reaction to the worsening of the market situation and the high intensity of recovery. The worst situation is represented by the fourth field where the intensity of the price fall is high and the intensity of the subsequent recovery is below average. Figure 8 shows the situation of stock market macrosectors at the time of the analysed period I and period II. The situation of the macrosectors can be characterised as follows:

- services - situation during the crisis and in the bear market was almost identical; the location in the first area (low-low) indicates a weak response to the downward stock market trends,

- financials - the location in the second area (high-high) suggests a strong response to the crisis periods, but also the considerable odds of recovery;

- $\quad$ industrials - during the crisis the macrosector was located in the third, best area (high recovery odds despite low risk of price decrease), while in the bear market it moved to the first area and was located in the close vicinity of the intersection of the axes (values: 1 and 1), which implies a reaction close to the average.

Obtained conclusions are convergent with the analysis of risk and odds ratios performed by means of the logit model [Bieszk-Stolorz, Markowicz, 2017]. 


\section{Conclusions}

The article presents the findings of the analysis of macrosector stock price movements of WSE companies in two periods: 2008-2009 and 2011-2013. The study is divided into stages pursuant to the adopted specific objectives.

The hypothesis about a similar situation of macrosectors during the financial crisis and in the bear market was confirmed. Comparing the situation of specific macrosector with relations to the remaining ones we can state that it was the same in both periods. In case of the financials macrosector, its reaction to the market situation was the strongest in both the decrease and increase of share prices. The companies of the industrials macrosector were in better situation than the financial companies (less intensive price decrease and small difference in the intensity of increase). The service companies reacted weakly to the market changes. It should be noted that none of the macrosectors was in the fourth area (high-low). This refers to the worst situation - high intensity of decrease and low intensity of increase.

Summing up the presented results it could be stated that companies strongly reacting to a period of price decrease are in the worst situation. It is due to the fact that it requires from the board members appropriate decisions and resources. In both analysed periods such situation was for the companies in the financials macrosector. Amongst them the largest fraction of companies reached the set threshold decrease value and reached it the quickest. The intensity of this decrease was also the largest.

\section{References}

Balicki A., 2006, Analiza przężycia i tablice nymieralności, PWE, Warszawa.

Bieszk-Stolorz B. Markowicz I., 2011, Wykoraystanie modelu proporcionalnego hazardu Coxa do oceny crasu od spadku cen akcji spótek giełdowych w okresie krysysu finansowego do ich w:rostu, „Prace Naukowe Uniwersytetu Ekonomicznego we Wrocławiu” nr 183, Wydawnictwo UE we Wrocławiu, Wrocław, pp. 47-54.

Bieszk-Stolorz B., Markowicz I., 2012, Modele regresji Coxa w analirie besrobocia, CeDeWu, Warszawa.

Bieszk-Stolorz B., Markowicz I., 2017, The assessment of the situation of listed companies in macrosectors in a bear market - duration analysis models, [in:] Gardoń A., Kozyra C., Mazurek E. (eds.), "Applications of Mathematics and Statistics in Economics 2017. Conference Proceedings Full Text Papers", 20th International Scientific Conference AMSE, Szklarska Poręba 30 th $^{\text {th }}$ August - 3 $3^{\text {rd }}$ September 2017, Wrocław, pp.17-26. DOI: 10.15611/amse.2017.20.02.

Cox D. R., Oakes D., 1984, Analysis of Survival Data, Chapman and Hall, London.

Deville L., Riva F., 2007, Liquidity and Arbitrage in Options Markets: A Survival Analysis Approach, "Review of Finance", vol. 11, issue 3, pp. 497-525, DOI: 10.1093/ rof/rfm021.

GPW database, http://www.gpw.pl/analizy_i_statystyki, access: 15.06.2016. 
Hosmer D. W., Lemeshow S., 2000, Applied Logistic Regression, John Wiley \& Sons. Inc., New York.

http://biznes.pl/gielda/profile/swiat/sp-500-us.402.2.6.profile-wykresy-s.html, access: 10.06.2016.

Kaplan E. L., Meier P., 1958, Nonparametric estimation from incomplete observations, "Journal of the American Statistical Association", vol. 53, no. 282, pp. 457-481, DOI: $10.2307 / 2281868$.

Kleinbaum D. G., Klein M., 2005, Survival Analysis. A Self-Learning Text, SpringerVerlag, New York.

Landmesser J., 2013, Wykoraystanie metod analisy czasu trwania do badania aktywności ekonomicznej ludności w Polsce, Wydawnictwo SGGW, Warszawa.

Lunde A., Timmermann A., 2004, Duration Dependence in Stock Prices: An Analysis of Bull and Bear Markets, "Journal of Business \& Economic Statistics", vol. 22, no. 3, pp. 253-273, DOI: 10.1198/073500104000000136.

Markovitch D. G., Golder P. N., 2008, Findings - Using Stock Prices to Predict Market Events: Evidence on Sales Takeoff and Long-Term Firm Survival, "Marketing Science", vol. 27, issue 4, pp. 717-729, DOI: 10.1287/mksc.1070.0325.

Markowicz I., Stolorz B., 2009, Model proporcjonalnego hazardu Coxa prayy różnych sposobach kodowania zmiennych, „Przegląd Statystyczny”, vol. 2, issue 56, pp. 106-115.

Olbryś J., Majewska E., 2015, Bear Market Periods During the 2007-2009 Financial Crisis: Direct Evidence From the Visegrad Countries, „Acta Oeconomica”, vol. 65(4), pp. 547-565, DOI: 10.1556/032.65.2015.4.3.

Rocznik Gietdony 2012, https://static.gpw.pl/pub/files/PDF/rocznik2012/GPW 102_Rocznik2012_Final.pdf. access: 12.06.2016. 